\title{
INVESTIGATING THE SPREAD OF CORONAVIRUS (COVID-19) AT AIRPORTS AND METHODS OF PROTECTION
}

Sawsan H. Al-Mashhadani ${ }^{1}$
"Zainab T. Al-Sharify ${ }^{2}$
Nagam Obaid Kariem ${ }^{3}$

1) M.Sc student, Department of Environmental Engineering, College of Engineering, Mustansiriya University, P.O. Box 14150, Babal-Mu'adhem, Baghdad, Iraq.

2) Lecturer, Department of Environmental Engineering, College of Engineering, Mustansiriya University, P.O. Box 14150, Bab-alMu'adhem, Baghdad, Iraq

3) Assit Professor, Head of Environmental Engineering Department, College of Engineering, Mustansiriya University, P.O. Box 14150, Bab-al-Mu'adhem, Baghdad, Iraq.

\begin{abstract}
COVID-19 is believed to have originated in the city of Wuhan, China around December 2019. This virus spreads very easily, through human to human contact, or touching surfaces which may possibly contain the virus. Through this transmission, travelling passengers and airports are under attack the most. In this study, we will investigate Iraq's largest airport, Baghdad International Airport and the passenger travel trend. The study will also provide an insight on various screening method that were introduced to track the symptoms of the virus.

Overall, in the present times, several regulations are being operated in many airports around the world to control different pollution types such as air pollution. Amidst these pollutants, the occurrence of coronaviruses is troublesome and there is an urgent need to identify safety precautions which can be adopted to prevent the spread of COVID-19, specifically at airports.
\end{abstract}

Keywords: Coronavirus, COVID-19, Baghdad International Airport, Pollution, Pollutants

\section{Introduction}

In the year 1999, the Dutch government investigated the health impacts at airports for a study labelled "Public health impact of large airports" and observed noise and air pollution levels [1]. The report states that the contribution from aircraft and traffic have a mixed impact on public health. This is due to the dispersion of air pollutants in the atmosphere and the total pollution is contributed by other sources. This results in a similar quality of air around airports and urban locations with road traffic having a higher impact. The committee concludes that air pollution at different levels is observed at airports and has little correlation to the frequency of hospital emissions and the deaths. This is primarily due to respiratory infections, cardiovascular complications, and reduced function of the pulmonary system. It also states that epidemiological research has also provided results of long term exposure to the effects of air pollution. Further investigation also shows that chronic exposure to air pollution causes morbidity and mortality. It is also obvious that air pollutants also contribute to the disorder of cells and can cause cancer [2].

Airplane traffic is a major cause of air pollution near airport areas. The effects are not limited to airports premises but it affects the urban residents near the airport. The ultrafine Sulphur dioxide, nitrogen dioxide and other particles are formed due to condensation of jets hot exhaust vapours. These particles enter inside the lungs 
and pass through the blood. As a result, the pulmonary disease and asthma is developed in residents of nearby areas. The researchers also showed that children living near the airport are suffering from asthma as compared to residents of faraway places. The pollution near the airport is very dangerous as blood pressure and digestive system affected badly. The high level of noise disturbs sleep and stress levels are increased [3-5].

The main pollutants are diesel exhaust, carbon monoxide and leaked chemicals which make the residents asthma patients. The main pollutant is $\mathrm{NO}_{2}$ and it produces ozone. The ozone act as a pollutant in the lower atmosphere and causes global warming [3, 4].

The COVID-19 epicentre was located as the city of Wuhan in China, where the WHO declared this virus as a global pandemic in March 2020 [5, 6]. Differnt medical methods and medical imaging techniques were used to diagnose corona viruse in the infected patient [6-8]. The international interest seemed not significant in the public health crisis initially therefore information about the transmission of the virus is limited. Different countries are initiating different approaches to halt the spread of COVID-19. The use of disinfectants is the most cost and time-effective solution as has been demonstrated in different countries. Certain countries with very busy airports and transit points have closed their borders and reduced or cancelled flights from heavily infected countries. A quarantine period of 14 days and fever scanners have been recommended. The number of cases varies from one country to another and it is very high in some places and zero in other areas. All the countries are united and working hard to decrease the speed of the spread of COVID-19. In this connection, airports are a big challenge to control the spread of COVID -19 as passengers enter in the country are big carriers [9].

This study has, for the first time, evaluated data on international and domestic air traffic at Baghdad International Airport, Iraq's largest airport; patterns were analysed to understand the impact of air travel. The study also demonstrates the trend of COVID-19 cases and deaths in Iraq.

\section{Methodology}

The current interest is in humans using air transportation vehicles or hubs where they are exposed to influenza, SARS-CoV, or MERS$\mathrm{CoV}$ via the breathed or touched environment. Qualitative and quantitative evidence of acceleration and/or amplification of pathogen transmission related to the transport systems was gathered in this study. This paper was concerned with estimating the risk of transmission related to the use of transport systems, not the timing of pandemics or the effectiveness of specific interventions. COVID19 disease had peaked in China initially and in mid-February, it alarmingly spread in Iran.

To elaborate, the flights of Mahan Airlines to Iraq, Lebanon and Syria were halted after reporting the following cases:

1. The first case of infection was recorded in Lebanon on February 26, 2020, for a Lebanese woman returning from Iran on February 20, 2020, on flight number (W51152) belonging to the company (Mahan Air).

2. The first case of infection was recorded in Iraq on February 24, 2020, for an Iranian student returning from Tehran to Najaf on 
February 19, 2020, on flight number (W55062) from Mahan Air.

3. First COVID-19 case was registered in Syria on March 3, 2020 for a woman returning from air travel (destination is not specified).

The total COVID-19 confirmed cases of for Iraq were sourced from the situation reports on COVID-19 made publicly available by WHO and other agencies.

\section{Results and Discussion}

From the foregoing, the role of air transport in the transmission of the virus from its origin to many countries within a few days and weeks is evident if appropriate measures are not taken to limit this issue.

The spread of the virus in Iraq continued to proceed at a slow pace at first, until the infections began to multiply within the first 100 days of recording one infection on 24/2/2020 to the end of May of the same year, where the numbers of infections were recorded for the day 5/29/2020 in Iraq (416) (New case, Baghdad, (265) new cases were registered, constituting $63.7 \%$ of all cases in Iraq

And the export of one case via air transport to Iraq on 23/2/2020 arrived after (100) days to (5873) and in Baghdad that it (3053) injuries.

In Figure 1, the diagram shows the comparison between the number of daily confirmed positive cases in Baghdad and Iraq as a whole during (100) days from the schedule, where it becomes clear in the last twenty days of the crisis that the number of casualties in Baghdad increased and represented a large proportion of the numbers of Iraq cases.
As for Figure No. (2), it shows the cumulative numbers of cases during the same period in Baghdad and Iraq, where it turns out that Baghdad, the number of cases in Baghdad reached (3221) and in Iraq (6179) until $30 / 5 / 2020$, including more than half of Iraqi injuries.

In this work, the analyzing of the movement of flights inside Iraq for Iraqi Airways only (the lack of data of the movement of other airlines inside Iraq) during the Corona pandemic period, as flights were first stopped with China and the date of return of the last flight from Quanzhou was on 13/2/2020 and after Besides, the movement of aircraft was reduced until the Iraqi Civil Aviation Authority issued a decision to suspend flights covering all local airports in the country, starting from $3 / 16 / 2020$, the exception of planes crossing Iraqi airspace, in response to precautionary and preventive measures to prevent the spread of the emerging Coronavirus. Then, exceptional flights were resumed since the date of the evacuation of Iraqis stranded in many countries of the world.

Table 1 represents a summary of the numbers of exceptional flights to evacuate Iraqis, their numbers, the names of countries and the destinations coming from it, and for the indicated periods for each that were implemented by the General Company for Iraqi Airways affiliated with the Iraqi Ministry of Transport in the light of the Corona pandemic and for the period between (3/22/2020 to 5/27) 2020).

It appears from the information in the table that after the execution of the flight attendants, since the date of 3/16/2020, Iraq began to evacuate Iraqis stranded abroad, and approximately (82) trips were implemented and approximately 
(15648) passengers from (22) travel destinations were entered during the period. The period from $(3 / 22 / 2020$ to $5 / 27 / 2020)$, which is the period during which the Coronavirus began to record accelerated numbers of infections in Iraq in general and in Baghdad in particular.

The figure (3) shows the following:

1. Date of the first COVID-19 case on February 24, 2001.

2. The date of the first exceptional flight in $22 / 3 / 2020$, almost one month after the first case was recorded.

3. It is noted that with the commencement of exceptional flights, the number of confirmed infections recorded doubled and that the largest share of the city of Baghdad (taking into account the incubation period of the virus in the human body and the emergence of symptoms of infection ranging from 2-14 days) because of the fact that exceptional flights land in Baghdad International Airport exclusively to close the rest of the major Iraqi airports, except in very exceptional circumstances.

4. The World Health Organization has indicated on $(2 / 5 / 2020)$ that the reasons for the high number of coronavirus infections in Iraq are the lack of consideration by citizens of the preventive measures and the many gatherings due to the partial urban lift, as well as the increase in comprehensive surveys initiated by the Ministry of Health as part of its strategic plan for the regional survey and search for the cases. As a result of this analysis, we expect that to increase the number of Iraqis returning to Iraq from different countries in light of this global pandemic, a role in increasing cases inside Iraq, especially as the incubation period of the disease is relatively long and the possibility of infection by contact by someone who does not complains of any symptoms, despite the presence of medical teams at the airport to examine the travelers entering Iraq (as shown in Figure 4) and the quarantine procedures for the infected, but it was proven that there was infection by people returning from travelling to people in contact with them after the end of the quarantine period of (14) days.

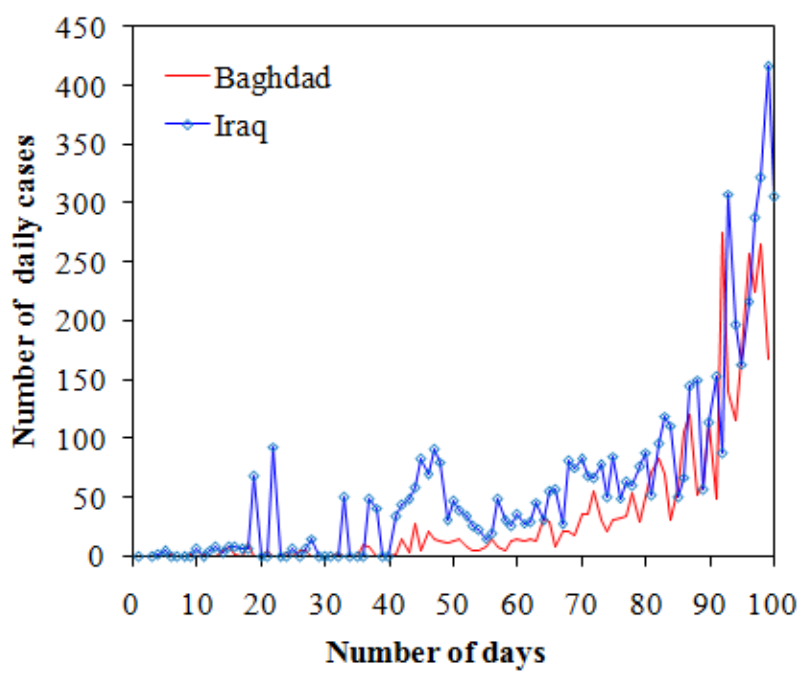

Figure 1.The comparison between the number of daily confirmed positive cases in Baghdad and Iraq as a whole during (100) days from the schedule International Airport from $23 / 2 / 2020$ to $30 / 5 / 2020$ [10].

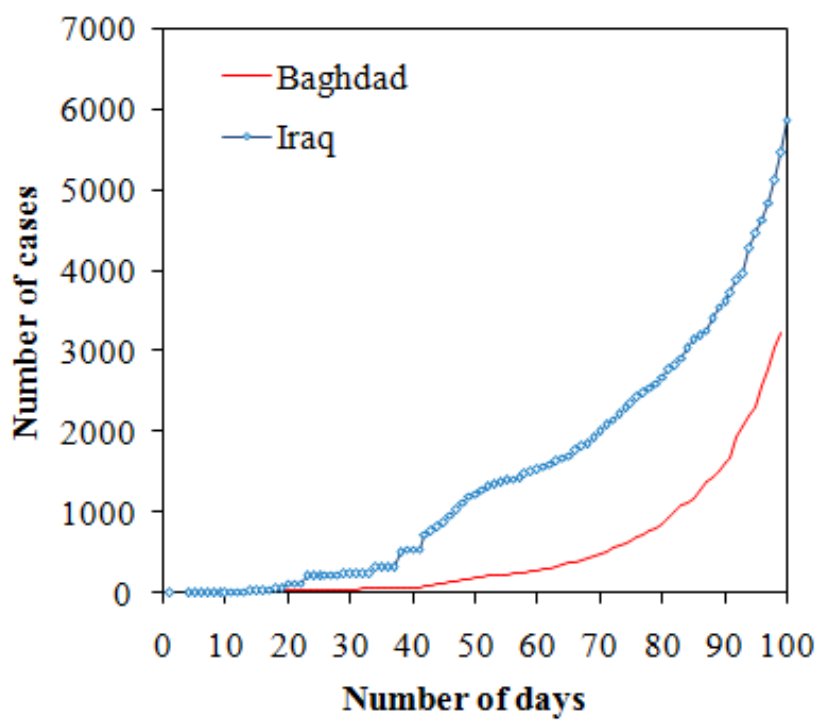

Figure 2.The cumulative numbers of cases in Baghdad and Iraq, International Airport (10) 
Table 1. Summary of the numbers of exceptional flights to evacuate Iraqis

\begin{tabular}{|c|c|c|c|c|c|}
\hline & From & To & & & Date \\
\hline & $\begin{array}{c}\text { /City } \\
\text { Country }\end{array}$ & & $\begin{array}{l}\text { number } \\
\text { of trips }\end{array}$ & $\begin{array}{l}\text { passengers } \\
\text { arriving }\end{array}$ & From/to \\
\hline 1 & $\begin{array}{l}\text { ¿Delhi } \\
\text { /Bungalow } \\
\text { India }\end{array}$ & Baghdad & 8 & 1491 & $\begin{array}{l}22 / 03 / 2020 \\
29 / 04 / 2020\end{array}$ \\
\hline 2 & $\begin{array}{l}\text { /Cairo } \\
\text { Egypt }\end{array}$ & Baghdad & 17 & 3349 & $\begin{array}{l}24 / 03 / 2020 \\
05 / 05 / 2020\end{array}$ \\
\hline 3 & $\begin{array}{c}\text { /Moscow } \\
\text { Russia }\end{array}$ & $\begin{array}{c}\text { Baghdad } \\
\text { Basra }\end{array}$ & 9 & 2045 & $\begin{array}{l}29 / 03 / 2020 \\
27 / 05 / 2020\end{array}$ \\
\hline 4 & $\begin{array}{l}\text { ‘Mashhad } \\
\text { /Tehran } \\
\text { Iran }\end{array}$ & Baghdad & $\varepsilon$ & rAA & $\begin{array}{l}19 / 04 / 2020 \\
25 / 05 / 2020\end{array}$ \\
\hline 5 & $\begin{array}{c}\text { /Dubai } \\
\text { UAE }\end{array}$ & $\begin{array}{c}\text { Baghdad } \\
\text { Erbil }\end{array}$ & 6 & 1141 & $\begin{array}{l}30 / 03 / 2020 \\
15 / 05 / 2020\end{array}$ \\
\hline 6 & $\begin{array}{c}\text { /Beirut } \\
\text { Lebanon }\end{array}$ & Baghdad & 2 & 230 & $\begin{array}{l}30 / 03 / 2020 \\
18 / 04 / 2020\end{array}$ \\
\hline 7 & $\begin{array}{c}\text { Minsk } \\
\text { Belarus/ }\end{array}$ & Baghdad & 1 & 115 & $31 / 03 / 2020$ \\
\hline 8 & $\begin{array}{c}\text { ‘Ankar } \\
\text { Istanbul } \\
\text { / Turkey }\end{array}$ & $\begin{array}{c}\text { Baghdad } \\
\text { Erbil }\end{array}$ & 8 & 1586 & $\begin{array}{l}01 / 04 / 2020 \\
07 / 05 / 2020\end{array}$ \\
\hline 9 & $\begin{array}{c}\text { /Amman } \\
\text { Jordan }\end{array}$ & $\begin{array}{c}\text { Baghdad } \\
\text { Erbil }\end{array}$ & 16 & 3497 & $\begin{array}{l}02 / 04 / 2020 \\
21 / 05 / 2020\end{array}$ \\
\hline 10 & $\begin{array}{c}\text { ‘Berlin } \\
\text { /Frankfurt } \\
\text { Germany }\end{array}$ & $\begin{array}{c}\text { Baghdad } \\
\text { Erbil }\end{array}$ & 3 & 545 & $\begin{array}{l}18 / 04 / 2020 \\
22 / 05 / 2020\end{array}$ \\
\hline 11 & $\begin{array}{c}\text { /Jeddah } \\
\text { Saudi } \\
\text { Arabia }\end{array}$ & Baghdad & 1 & 172 & $13 / 04 / 2020$ \\
\hline 12 & $\begin{array}{l}\text { /Khartoum } \\
\text { Sudan }\end{array}$ & Baghdad & 1 & 95 & $05 / 05 / 2020$ \\
\hline 13 & $\begin{array}{l}\text { /Yerevan } \\
\text { Armenia }\end{array}$ & $\begin{array}{c}\text { Baghdad } \\
\text { Erbil }\end{array}$ & 1 & 53 & $29 / 04 / 2020$ \\
\hline 14 & $\begin{array}{c}\text { / Baku } \\
\text { Azerbaijan }\end{array}$ & Baghdad & 1 & 172 & $22 / 04 / 2020$ \\
\hline 15 & $\begin{array}{c}\text { Kuala } \\
\text { /Lumpur } \\
\text { Malaysia }\end{array}$ & Baghdad & 2 & 468 & $\begin{array}{l}13 / 04 / 2020 \\
26 / 04 / 2020\end{array}$ \\
\hline 16 & $\begin{array}{c}\text { Kiev } \\
\text { Ukrainian/ }\end{array}$ & Baghdad & 1 & 187 & $08 / 05 / 2020$ \\
\hline 17 & $\begin{array}{l}\text { /Muscat } \\
\text { Oman }\end{array}$ & Baghdad & 1 & 114 & $22 / 04 / 2020$ \\
\hline \multicolumn{3}{|c|}{ sum } & 82 & 15648 cap & \\
\hline
\end{tabular}

In the initial stages, temperature scanners were installed, and health workers were inspected for general symptoms assigned with the virus, such as coughing and shortness of breath. This method proved to be inefficient as no cases were detected, as the incubation period is more than 5 days. Therefore, the symptoms do not show itself and this tactic was discarded after a certain period of time. The authorities soon realised this, and a quarantine period of 14 days was recommended for travellers. This also prevented transmission to close family members due to the quarantine restrictions [11-13].

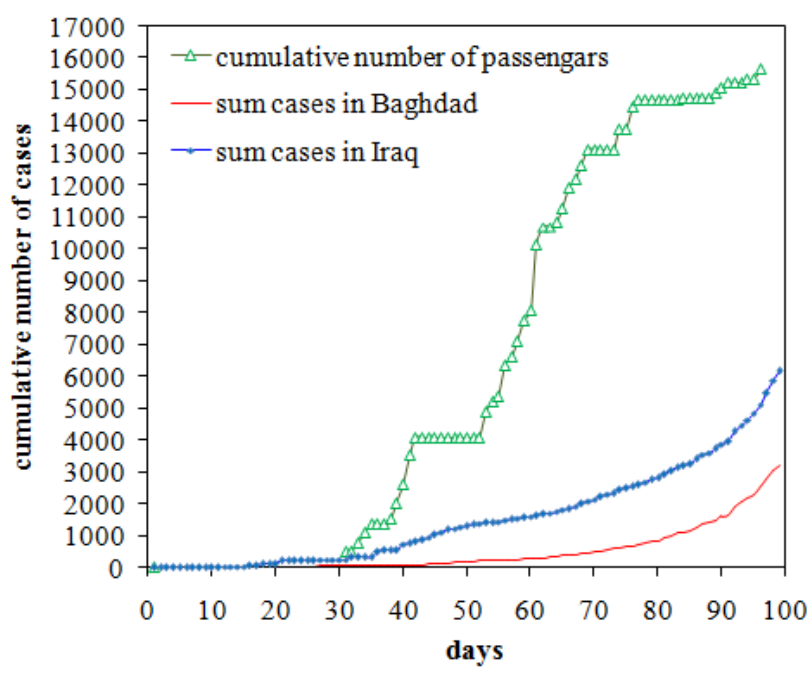

Figure 3.Analysis of increased cases of confirmed cases of COVID- 19 with the increasing of extraordinary flights to evacuate Iraqis from outside the country [10]

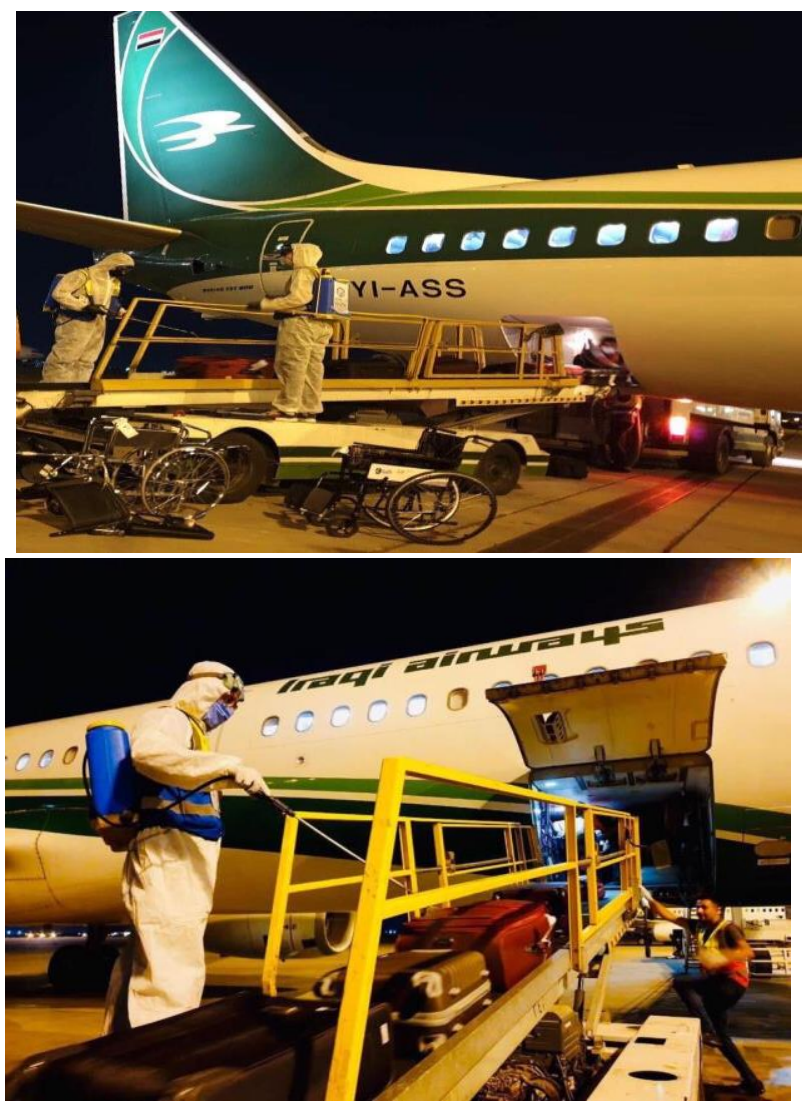




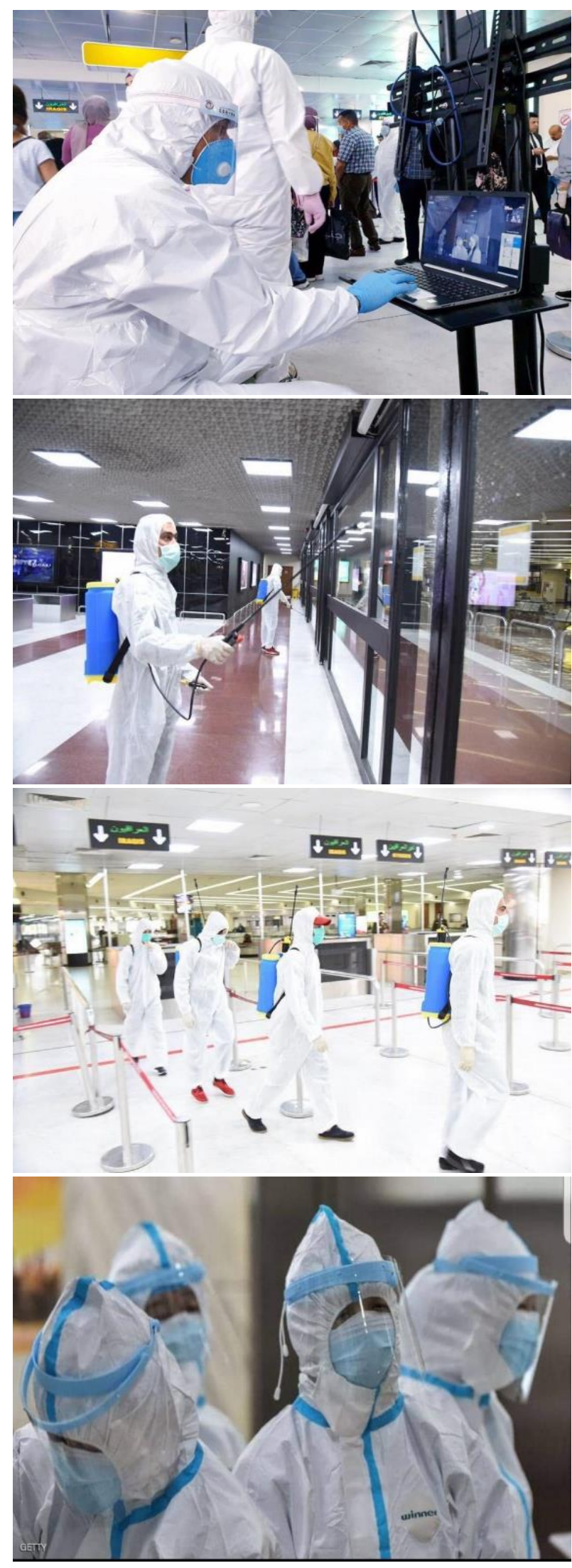

Figure 4.An illustration of prevention measures adopted to prevent the spread of COVID-19 at Baghdad International Airport

\section{Conclusions and Further work}

COVID-19 is believed to spread very easily, through human to human contact, or touching surfaces which may possibly contain the virus. Through this transmission, travelling passengers and airports are under attack the most. In this study, Iraq's largest airport, Baghdad International Airport, and the passenger travel trend was investigated.

Overall, in the present times, several regulations are being operated in many airports around the world to control different pollution types such as air pollution. All these pollutants form lots of harmful chemicals and therefore the concentration of total hydrocarbons and nonmethane hydrocarbons, carbon monoxide, airborne, particulate leads and smoke in the ambient air should be measured at different locations at the airport and in the vicinity of airports. Amidst these pollutants, the occurrence of corona viruses is troublesome and there is an urgent need to identify safety precautions which can be adopted to prevent the spread of COVID19 , specifically at airports.

For future work, this study can be expanded to present the results of an investigative survey which will be performed to understand public's views on ways to prevent the spread of COVID19 at airports. In the future study, each method will be studied along with describing the risk level at airports.

\section{Acknowledgements}

The authors acknowledge the support of Mustansiriyah University for their support with this work and would like to acknowledge the support of the ministry of health and environment in Iraq and their valuable work during this hard time. 


\section{Conflict of interest}

The authors confirm that there is no conflict on interest.

\section{References}

1. Akehurst, C., 1999. The impact of large airports on public health. Weekly releases (1997-2007), 3(40).

2. Airportwatch.org.uk. 2020. Airportwatch | Air Quality. [online] Available at: $<$ https://www.airportwatch.org.uk/briefings/a ir-quality-briefings-and-information/> [Accessed 30 May 2020].

3. Touri, L., Marchetti, H., Sari-Minodier, I., Molinari, N. and Chanez, P., 2013. The airport atmospheric environment: respiratory health at work. European Respiratory Review, 22(128), pp.124-130.

4. Trasande, L. and Thurston, G., 2005. The role of air pollution in asthma and other pediatric morbidities. Journal of Allergy and Clinical Immunology, 115(4), pp.689-699.

5. Murtadah, I., Al-Sharify, Z. T., \& Hasan, M. B., 2020. Atmospheric Concentration Saturated and Aromatic Hydrocarbons Around Dura Refinery. In IOP Conference Series: Materials Science and Engineering (Vol. 870, No. 1, p. 012033). IOP Publishing.

6. WHO. 2020. Coronavirus Disease 2019 (COVID-19). WHO. Situation Report 23.

7. Al-Sharify, N. T., Al-Sharify, Z. T., AlSharify, T. A., Al-Sharify, M. T., and AlSharify, A. T. 2020. A Technical Overview and Comparison between PET and MRI Scanning. Systematic Reviews in Pharmacy, 11(1), 35-41.

8. Al-Sharify, Z. T., Al-Sharify, T. A., and AlSharify, N. T., 2020. A critical review on medical imaging techniques (CT and PET scans) in the medical field. In IOP Conference Series: Materials Science and
Engineering (Vol. 870, No. 1, p. 012043). IOP Publishing.

9. Lau, H., Khosrawipour, V., Kocbach, P., Mikolajczyk, A., Ichii, H., Zacharski, M., Bania, J. and Khosrawipour, T., 2020. The association between international and domestic air traffic and the coronavirus (COVID-19) outbreak. Journal of Microbiology, Immunology and Infection,

10. Worldometer. 2020. COVID-19 CORONAVIRUS PANDEMIC. [online]. Available at: https://www.worldometers.info/coronavirus/

11. Elbaldawi, L., 2020. Is Iraq Taking Necessary Measures To Prevent COVID-19 Spread?. [online] Al-Monitor. Available at: https://www.almonitor.com/pulse/originals/2020/03/iraqcorona-virus-religion-health.html

12. Icao.int. 2020. [online] Available at: $<$ https://www.icao.int/Security/COVID19/StateActions/China.pdf> [Accessed 30 May 2020].

13. Urso, D., 2020. Coronavirus Disease 2019 (COVID-19): A Brief Report. Clinical Management Issues, 14(1). 